\title{
Globalisation and Convergence of International Life Insurance Markets
}

\author{
Chien-Chiang Lee* and Chi-Hung Chang \\ Department of Finance, National Sun Yat-Sen University, Kaohsiung 804, Taiwan. \\ E-mails: cclee@cm.nsysu.edu.tw; t1212516@ms37.hinet.net \\ *Corresponding author
}

Using panel data of 39 countries over the period 1979-2007, this paper is the first to empirically examine the influence of the KOF index of globalisation (overall and its three main sub-indices) on the development and convergence of international life insurance markets by a panel cointegration technique. We find that globalisation has a significant impact on the development of international life insurance markets and on reducing the deviation between individual countries' life insurance penetration and the world average. Economic and social dimensions exert a similar effect as well, and the effect of economic globalisation is higher, while the effect of political dimension is not significant. In addition, social globalisation plays a dominant role on the interactive influence of different dimensions of globalisation, implying that socio-cultural factors are a latent factor behind economic or political influence. Finally, most countries' structural breaks coincide with the fast growth wave of international life insurance markets.

The Geneva Papers (2012) 37, 125-154. doi:10.1057/gpp.2011.34

Keywords: globalisation; life insurance; convergence; social dimension; panel cointegration analysis

\section{Introduction}

Since globalisation is a trend in world development, a vast number of studies have sought to demonstrate whether globalisation is beneficial to economic or financial performances, though most previous ones only consider the sub-dimensions of globalisation such as openness to trade flows, capital mobility or the economic aspect. To our knowledge, no published literature has so far investigated empirical evidence on the relationship between a broad measure of globalisation and the activities of insurance markets. This paper herein is the first to investigate the influence of globalisation on the development and convergence of international life insurance markets using the panel data cointegration technique. ${ }^{1}$ Using data of 39 countries over the period 1979-2007, we evaluate the effect of overall globalisation as well as of different dimensions of globalisation, including economic, social and political dimensions, on the development and the deviation of life insurance across countries. This paper emphasises that globalisation is not only an economic phenomenon, but

\footnotetext{
${ }^{1}$ Life insurance is a form of insurance coverage that pays out premiums to the insured or their specified beneficiaries upon a certain incident.
} 

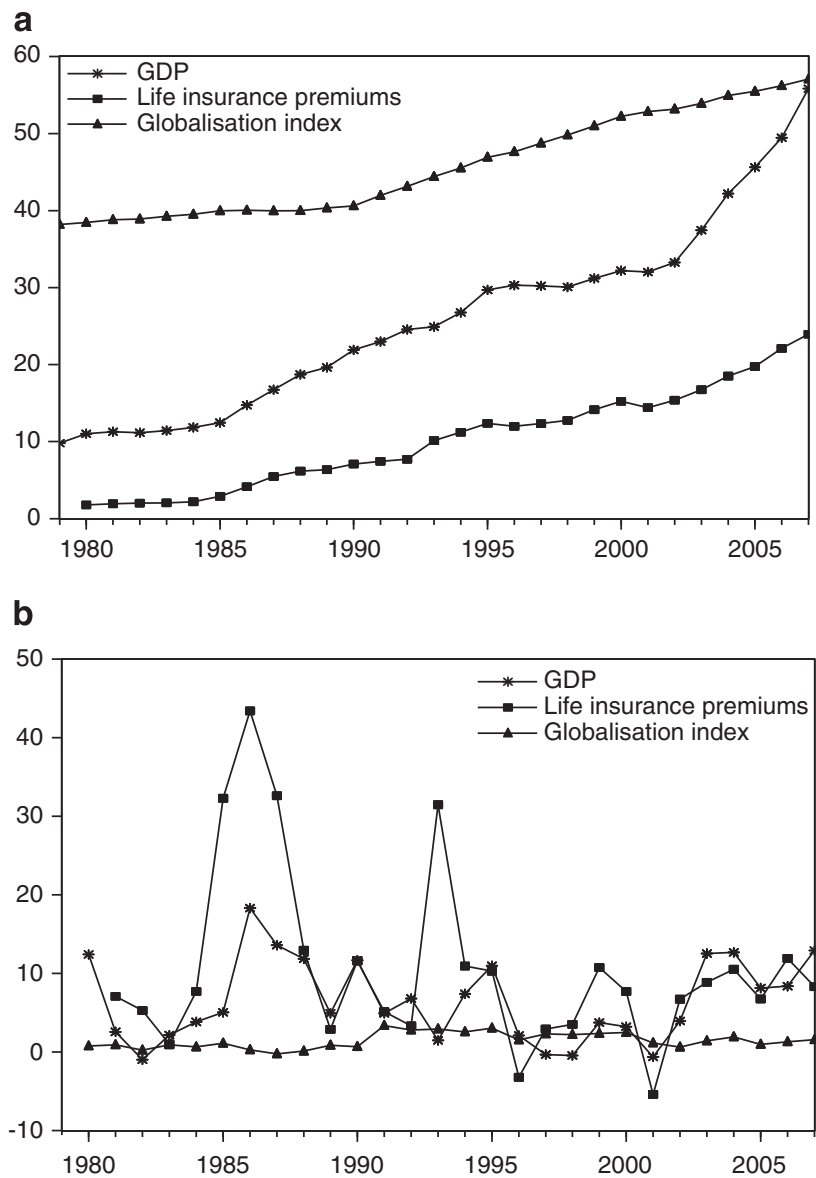

Figure 1. The trend of the world GDP, life insurance premiums and globalisation index: (a) Level (Note: The vertical axis is represented respectively as follows: GDP in trillion U.S. dollars, life insurance premiums in hundred billion U.S. dollars and globalisation index in units); (b) Growth rate (Note: The vertical axis is growth rate).

that it is also important to take into consideration a variety of different aspects associated with global development.

The development of life insurance markets worldwide, measured by life insurance premiums, progresses with economic development, proxied by gross domestic product (GDP), and the evolvement of globalisation. As Figure 1a shows, the world's life insurance premiums rise with the increase in the world's GDP and in the degree of globalisation. ${ }^{2}$ The growth of life insurance premiums even follows the growth pattern of GDP generally, with a higher magnitude in most occasions, as shown in Figure 1b. For instance, in the period 1986-1988 the world's GDP grew in an annual growth rate

\footnotetext{
${ }^{2}$ World premiums data is taken from Sigma published by the Swiss Reinsurance Company.
} 
of above 10 per cent (in current U.S. dollars), so did the growth of the world's life insurance premiums, which is over 30 per cent in 1986 and 1987. The change of globalisation is not substantial, which should be expected as globalisation usually proceeds in a gradual and continued process. Figure $1 \mathrm{~b}$ shows that life insurance premiums have higher growth rates in the following periods: more than 30 per cent in 1985-1987 and 1993, and 10 per cent in 1988, 1990, 1994, 1995, 1999, 2004 and 2006. Negative growth rates are, however, observed in 1996 and 2001. These unusual circumstances imply the existence of possible structural changes in life insurance markets worldwide. We examine this issue in the later section.

This paper contributes to the literature in the following ways. First, we apply a new panel technique to examine the long-run relationship between life insurance markets and the indices of globalisation. Employing panel data econometrics allows us to take into consideration the presence of heterogeneity in the estimated parameters and dynamics across countries and increases the reliability of the findings resulting from cross-country analysis. Unlike the time-series or traditional static panel data approach, the panel cointegration model selectively pools the long-run information contained in the panel but also allows the short-run dynamics and fixed effects to be heterogeneous among different countries within the panel. ${ }^{3}$ We further utilise the panel cointegration model with structural breaks extended by Westerlund ${ }^{4}$ to examine if there are structural changes in life insurance markets worldwide.

Next, existing studies document the possible influence of globalisation on insurance development from points of theoretical description, ${ }^{5}$ and we empirically verify the impact of globalisation. Finally, an analysis on alternative dimensions of globalisation enables us to identify which dimension of globalisation plays a more important role on life insurance development and how various aspects of globalisation influence each other. One of our findings - the interaction term of social globalisation has a significant impact on the specification of the economic or political dimension-implies that socio-cultural factors may play a latently moderate role behind the influence of economic and political aspects. This finding is somewhat consistent with Pepinsky's $^{6}$ notion that the route towards financial development cannot deviate from the broader social and political structures in which economic action takes place. In a robust analysis, we show that the effect of globalisation is unaltered even after controlling for the influence of economic development, that is, the globalisation does affect the development of life insurance markets but not merely proxy for economic development.

Understanding the influence of globalisation on the development and the convergence of international life insurance markets is quite beneficial. From the position of policymakers, globalisation is associated with liberalisation or openness related to economic, political or socio-cultural aspects within the economy. If globalisation impacts life insurance markets, then policymakers' attitude towards

\footnotetext{
${ }^{3}$ Pedroni (2000).

${ }^{4}$ Westerlund (2006).

${ }^{5}$ Enz (2000) and Cummins and Venard (2008).

${ }^{6}$ Pepinsky (2010).
} 
globalisation may in turn indirectly affect the markets. For the insurance industry, if globalisation does promote life insurance markets' development, then insurers can focus on under-developed life insurance markets, because it implies the existence of opportunities if globalisation can promote the convergence of international life insurance markets, that is, towards the world average.

To this end, we first estimate a world life insurance growth curve based on life insurance penetration across countries. As it is difficult to estimate life insurance penetration worldwide, we adopt Enz's ${ }^{7}$ world insurance growth model to evaluate average penetrations around the world. The world life insurance growth curve, evaluated by a logistic function, is more appropriate than the simple international average method in that it takes into account the non-linear relationship between income and life insurance consumption. A smaller deviation value represents a lower difference of a country's life insurance penetration from the world's insurance penetration, indicating the convergence in international life insurance markets. We then attempt to investigate if globalisation could reduce the deviation level and which type of globalisation plays the most important role.

As factors that influence the development of life insurance markets come from economic and socio-cultural aspects, ${ }^{8}$ we examine the effect of overall globalisation as well as of sub-dimensions, including economic, social and political dimensions. Using the KOF index of globalisation developed by Dreher, ${ }^{9}$ we find that globalisation exerts a significant effect on life insurance markets' development and on the reduction of the deviation in international life insurance markets. Among the sub-indices, economic and social dimensions individually have a similar influence, and economic globalisation has a higher effect. The political factor, however, neither influences life insurance development nor does it lead to a reduction in the deviation of life insurance markets across countries. Furthermore, in an interactive analysis the interaction term of social aspect exerts a significant influence on the economic or political specification, whose interaction term does not, however, have a significant effect in social specification. Finally, in a panel cointegration test with multiple structural breaks, we find that most countries have structural break points coincident with the fast growth period of the world life insurance market - a phenomenon that might be derived from globalisation.

The paper proceeds as follows. The next section discusses the relation between globalisation and the development of international life insurance markets. The subsequent section describes the econometric methods and the data. The penultimate section presents the empirical findings and implications, while the final section presents the conclusions.

\section{Globalisation and international life insurance markets}

Cummins and Venard ${ }^{10}$ document that global similarities such as deregulation, intensification of competition and, generally, rapid growth in insurance sales in

\footnotetext{
${ }^{7}$ Enz (2000).

${ }^{8}$ Beck and Webb (2003), Chen et al. (2011) and Lee and Chiu (2012).

${ }^{9}$ Dreher (2006a).

${ }^{10}$ Cummins and Venard (2008).
} 
insurance markets worldwide are reshaping insurance markets. Several homogeneous trends bring about a closer association of international insurance markets, including the similarity of insurance products, the emergence of innovative products such as universal life insurance and variable life insurance and annuity, the frequent occurrence of global risks, the revolution in information technology, the growing importance of supranational agencies such as the World Bank and the World Trade Organization (WTO), and so on.

Based on Cummins and Venard's ${ }^{10}$ argument, we infer that globalisation could gradually reduce the difference in the development of insurance markets across countries. $\mathrm{Enz}^{7}$ indicates that increased globalisation in the insurance sector might bring about an integration towards the world average. Di Vaio and Enflo ${ }^{11}$ show that globalisation has been accompanied by convergence of per capita income. As income is the most direct factor and exerts a positive impact on the purchase decision of insurance, it could be conjectured that the difference of insurance consumption across countries should diminish with the convergence of income level.

In addition to economic development level, factors in economic, socio-cultural and legal and political aspects affect the development of insurance markets. ${ }^{12,13}$ Some similar development trends among these factors may diminish the difference of life insurance development across countries. An expected trend that could bring life insurance markets worldwide to a similar avenue in the future comes from the demographic factor-ageing populations, which in turn might cause the change of social security systems, an economic determinant of life insurance demand. A welldeveloped social security system leads to less demand for life insurance and annuities. The ageing populations, however, disturb standard social security systems because fewer working age people have to shoulder the pension benefits of more and more retirees, pushing the country to introduce capital-backed pension systems that usually increase the demand for life insurance and annuities. According to the report by the United Nations, the population of older persons is growing globally at a rate of 2.6 per cent per year, considerably faster than the population as a whole with a growth rate of 1.2 per cent annually. ${ }^{14}$ The higher growth of the older population is expected to persist at least until 2050. Such rapid growth will necessitate extensive economic and social adjustments in most countries. Moreover, the potential support ratio (the number of persons aged 15-64 years for each older person aged 65 years or over) declined from 12 to nine potential workers per older person between 1950 and 2009, and will drop further to four by 2050. The reduction of the ratio has important implications for social security schemes, particularly for pay-as-you-go systems. The similarity in the population development across countries would reduce differences between countries' development of life insurance markets. As these trends are related to social or economic aspects within a country, this paper provides consistent findings

${ }^{11}$ Di Vaio and Enflo (2010).

${ }^{12}$ Hussels et al. (2005) and Lee and Chiu (2012).

${ }^{13}$ For the limitation of space, we do not delineate related factors here but refer interested readers to Hussels et al. (2005) for details.

${ }^{14}$ World population ageing 2009 (Population Division of the Department of Economic and Social Affairs of the United Nations). 
130

that globalisation in social and economic dimensions are more important in reducing the difference of life insurance markets across countries.

Another important trend is the increased importance of insurance markets in developing and emerging countries due to the high growth potential of their insurance markets. Zheng et al. ${ }^{15}$ indicate that the relative level of insurance growth in developing markets has increased and that the insurance industry in emerging markets and Brazil, Russia, India and China is even undergoing rapid development and has achieved a relatively high level. Berry-Stölzle et al. ${ }^{16}$ note that insurance market growth rates in emerging markets exceed those available in most developed countries, and high growth rates have attracted new and existing firms to these markets. Liberalisation and openness have raised the attraction of these markets, as demonstrated by Arena, ${ }^{17}$ who argues that the process of financial liberalisation has accelerated growth in insurance market activity during the last decade, particularly in emerging markets, and by $\mathrm{Ma}$ and Pope, ${ }^{18}$ who document that trade liberalisation is one important factor for the host country to attract international life insurers' participation. We exemplify two important growth markets, China and India, to illustrate more clearly the possible effects of globalisation or openness on the development of life insurance markets. ${ }^{19}$

Sun et al. ${ }^{20}$ indicate that the development of insurance markets in China can be divided into three stages: resumption and restoration (1980-1985), market-oriented reform (1986-1991) and opening up and rapid growth (1992-present). China began to open its insurance market in 1992. The average annual growth rate of life insurance premiums over the period 1992-2009 is 28.94 per cent compared to 21.74 per cent over the period 1986-1991. ${ }^{21}$ After China's entry into the WTO in 2001, many restrictions to foreign insurers were relaxed after the effectiveness of The Regulations on Administration of Foreign-Funded Insurance Companies in 2002. The annual growth rate over the period 2002-2009 is 23.19 per cent. The figures show that openness benefits the growth of life insurance markets.

Many international insurance companies started to enter China's insurance market in a faster pace after the opening of the market. In 2001, approximately only ten subsidiaries of foreign insurers or joint ventures in the life insurance sector operated in China, with a market share of about 1.94 per cent in premium. ${ }^{22}$ In 2009 , the number of foreign life insurers was 28 (59 life insurers in total), most of which are from developed economies such as Canada, the Netherlands, the United States, the United

${ }^{15}$ Zheng et al. (2009).

16 Berry-Stölzle et al. (2010).

17 Arena (2008).

${ }^{18} \mathrm{Ma}$ and Pope (2008).

${ }^{19}$ Globalisation is a complicated process involving different aspects within an economy. For the convenience of explanation, we interpret liberalisation and openness of national markets, although limited in scope, as a synonym of globalisation.

${ }^{20}$ Sun et al. (2007).

${ }^{21}$ Annual growth rates are computed by premiums in local currency adjusted for consumer price index. The same method is applied in the following computation. Data on premiums is obtained from Sigma published by Swiss Re, which provides data for China from 1986 onwards.

222002 Yearbook of China's Insurance (Editorial Committee of China's Insurance Yearbook). 
Kingdom, etc., with a market share of 5.23 per cent. ${ }^{23}$ International insurers will introduce more innovative products into the markets, which may further stimulate the demand for insurance. ${ }^{24}$

The effect of liberalisation on insurance development could also be observed in another fast growth market, India. Before 1999, the life insurance market in India is dominated by the Life Insurance Corporation (LIC), a nationalised monopoly created by merging all life insurers in $1956 .{ }^{25}$ In 1999, the passing of the Insurance Regulatory and Development Authority Act repealed the monopoly position of LIC. New licences were granted and the private sector was allowed into the insurance business in 2000 . The average annual growth rate of life insurance premiums increased substantially from 8.67 per cent over the period 1979-1999 to 20.78 per cent over the period 2000-2009. Although joint venture is the major access to the market because of the limitation of ownership up to 26 per cent, foreign companies from developed countries, for example, AIG, Allianz, ING, MetLife, etc., have entered the market since the opening. The number of private life insurance companies, the majority of which have foreign partners, increased from 12 in $2003^{25}$ to 23 in 2011 . The market share of private companies in the new underwritten business was only 2 per cent in the fiscal year 2001-2002 because LIC possessed the share of 98 per cent, ${ }^{26}$ but the share increased to 36 per cent as of January $2008 .^{27}$ The openness promotes growth and brings about changes for the life insurance market in India. The government is examining the possibility of increasing the share of foreign ownership to 49 per cent. ${ }^{28}$ It should be expected that the market will attract more foreign insurers in the future if this happens due to the high growth economy and the huge population.

\section{Methodology and data}

\section{Data}

The sample used consists of time-series data on 39 countries over the 1979-2007 period. ${ }^{29}$ The measure of globalisation takes the index recently developed by the KOF database of the Swiss Economic Institute ("Konjunkturforschungsstelle"), proposed

\footnotetext{
${ }^{23} 2010$ Yearbook of China's Insurance (Editorial Committee of China's Insurance Yearbook). In some relatively clustered areas of foreign insurers such as Beijing, Shanghai, Shenzhen and Guangdong, market shares of life insurers are 14.47 per cent, 16.97 per cent, 8.46 per cent and 8.2 per cent, respectively. Based on these figures, it might be inferred that foreign insurers could expand the market share with the spread of their businesses to other areas in the future.

${ }^{24}$ For instance, the product portfolio before 1999 mostly consisted of traditional policies with a share of 89.12 per cent of gross life insurance premiums in 1998. This percentage decreased to 30.19 per cent and premium income from innovative products such as participating and universal life policies accounted for 58 per cent in 2003 (Sun et al., 2007).

${ }^{25}$ Sinha (2007).

${ }^{26}$ The Insurance Regulatory and Development Authority (2003).

${ }^{27}$ Lepaud (2008).

${ }^{28}$ Chaudhary (2008).

${ }^{29}$ The number of countries and period is determined by the availability of insurance and globalisation data.
} 
by Dreher ${ }^{9}$ and updated in Dreher et al.'s study ${ }^{30}$ (see Table A1 of Appendix). The $2009 \mathrm{KOF}$ index of globalisation calculates an overall index (GLOB) as well as the three main dimensions of globalisation, including economic (ECO), social (SOC) and political (POL), as detailed in Dreher et al.'s study ${ }^{30}$ Higher values represent great globalisation, and all globalisation indices range between 0 (not globalised) and 100 (globalised). Data for real GDP per capita (in 2000 U.S. dollars) are obtained from World Development Indicators. Life insurance penetration (INS) data are obtained from Financial Structure Data set established by Beck and Demirgüç-Kunt ${ }^{31}$ who took insurance premiums data from Sigma reported by the Swiss Reinsurance Company. ${ }^{32}$

The KOF index of globalisation has been used to investigate the relationship between globalisation and economic growth. ${ }^{33}$ It has also been widely used to examine the impact of globalisation on social and economic dimensions of the country, including human welfare and quality of life, socio-cultural development, economic policy and so on. ${ }^{34}$ Several globalisation indices have been proposed but are not adopted due to their limitations. The World Markets Research Centre G-Index presented by Randolph ${ }^{35}$ is excluded because it focuses only on the economic aspects of the globalisation process. ${ }^{36}$ One oft-adopted multidimensional globalisation index is the A.T. Kearny/ Foreign Policy measure. This measure is, however, criticised for its ad hoc procedure of determining the weights of its components ${ }^{37}$ and the omission of important dimensions. ${ }^{9}$ Caselli $^{36}$ notes that variables in economic dimension of the A.T. Kearny/Foreign Policy measure determine 50 per cent of the value of the overall index, which may impair its multidimensionality. Another multidimensional index is the CSGR globalisation index prepared by Lockwood and Redoano, ${ }^{38}$ which is not utilised because currently its data are updated only up to 2004.

\section{Deviation of life insurance markets}

The growth in insurance premiums in an economy correlates intimately with GDP growth. The literature has indicated that the insurance premium grows non-linearly with the growth of GDP rather than in a linear pattern. Carter and Dickinson ${ }^{39}$ and $\mathrm{Enz}^{7}$ developed a logistic model to portray the relationship between insurance

${ }^{30}$ Dreher et al. (2008).

${ }^{31}$ Beck and Demirgüç-Kunt (2009).

${ }^{32}$ According to the Swiss Reinsurance Company (2008), life and non-life insurance business are categorised according to standard EU and OECD conventions, and accident and health insurance are counted as part of non-life insurance. Annuity is included when discussing life insurance. Therefore, life insurance premiums include life insurance and annuity business.

${ }^{33}$ Dreher (2006a, b) and Chang and Lee (2010).

${ }^{34}$ We do not list studies utilising the KOF index in order to save space but refer interested readers to the KOF website for details, http://globalization.kof.ethz.ch/papers/.

${ }^{35}$ Randolph (2001).

${ }^{36}$ Caselli (2008).

${ }^{37}$ Lockwood (2004).

38 Lockwood and Redoano (2005).

39 Carter and Dickinson (1992). 
penetration and GDP per capita. The logistic model is also called "the S-curve model" since it is characterised by the shape of the letter " $\mathrm{S}$ ". The S-curve model depicts that insurance penetration grows slowly at a low income level, but expands quickly after the income attains a certain level, and then maintains a plateau as an even higher income level is realised. This pattern is more consistent with the reality than the assumption embedded in the linear model. We thus estimate the world insurance development curve based on the logistic model.

The logistic function utilised in this paper is presented in Enz's study ${ }^{7}$ and expressed as follows:

$$
\text { pen }=\frac{1}{C_{1}+C_{2} C_{3}^{p c g d p}} \text {, }
$$

where pen is estimated life insurance penetration, $p c g d p$ is real GDP per capita, and $C_{1}$, $C_{2}$ and $C_{3}$ are estimated parameters. The difference, denoted as variable DEV, is then calculated by subtracting the estimated penetration fitted by Eq. (1) from the observed life insurance penetration, in absolute terms. DEV is thus a measure of the deviation level of a country's life insurance penetration relative to the world's average penetrations, evaluating the divergent extent of a country's life insurance development from the world's average level. A higher DEV value means a higher difference, positive or negative, between a country's life insurance penetration and the world's average penetration. This paper examines if globalisation has an impact on decreasing the deviation, that is, a negative relation, and which type of globalisation-the economic, social or political aspect - plays the most important role.

Two alternative models can also be applied to measure insurance growth: the simple linear model and the logarithmic linear model. Zheng et al. ${ }^{40}$ indicate that the two methods have some obvious limitations due to unrealistic assumptions and thus cannot be applied in a general model. The simple linear model assumes an identical growth rate for insurance premium and GDP, and the logarithmic linear model assumes a constant income elasticity of premium as well as a constant income elasticity of penetration. In contrast, the logistic model or the S-curve model considers the nonlinear effect of income on the demand for insurance. Although the logistic model ignores other factors such as social, political, cultural and demographic aspects, it is still preferable because studies have shown that the growth and development of the overall economy is the key factor for insurance growth in the long term.

We define the deviation of life insurance markets across countries as the difference, in absolute terms, between actual life insurance penetration and the estimated world average penetration. We interpret the reduction of this deviation as the convergence of international life insurance markets. In economics or financial literature, one usual used measure of income convergence is sigma convergence, meaning that the dispersion of real per capita GDP levels of a group of economies tends to decrease over time. ${ }^{41}$ Our definition here is different, but similar in spirit.

\footnotetext{
${ }^{40}$ Zheng et al. (2008).

${ }^{41}$ Sala-i-Martin (1996).
} 
134

\section{Panel unit-root tests}

Panel unit-root tests utilised in this paper include the Levin, Lin and Chu (LLC) test proposed by Levin et al., ${ }^{42}$ the Im, Pesaran and Shin (IPS) test by Im et al., ${ }^{43}$ and the Fisher-type augmented Dickey-Fuller (ADF) and the Fisher-type Philips-Perron (PP) test by $\mathrm{Choi}^{44}$ and Maddala and $\mathrm{Wu}{ }^{45}$ Levin et al. ${ }^{42}$ extend the ADF test to a panel setting, which can be expressed as follows:

$$
\Delta y_{i t}=\alpha_{i}+\beta_{i} y_{i, t-1}+\sum_{j=1}^{p_{i}} \rho_{i j} \Delta y_{i, t-j}+\varepsilon_{i t},
$$

where $\beta_{i}$ is restricted to be identical across countries, $y_{i t}$ is the value of $y$ for country $i$ in period $t$ with $i=1,2, \ldots, N$ and $t=1,2, \ldots, T, p_{i}$ is the number of lags in the ADF regression, and the error term $\varepsilon_{i t}$ is assumed to be independently and normally distributed random variables with zero means and finite unit variances $\sigma_{i}^{2}$.

Im et $a l .{ }^{43}$ relax the assumption of the Levin, Lin and Chu (LLC) test by allowing $\beta_{i}$ to vary across units under the alternative hypothesis, which implies that some or all of the individual series are stationary. The IPS test is more general as it allows for heterogeneity in the autoregressive coefficients across panel members. Heterogeneity results from the differences in country-specific characteristics.

Maddala and $\mathrm{Wu}^{45}$ and $\mathrm{Choi}^{44}$ proposed an alternative approach employing Fisher's ${ }^{46}$ results to derive the test that incorporates the $p$-values from individual unit-root tests. Maddala and $\mathrm{Wu}$ based their test statistic on the $p$-values of the separate Dickey-Fuller unit-root tests for each cross-section units. Under the assumption that the tests are independent, define $\pi_{i}(i=1,2, \ldots, N)$ as the $p$-values from individual unit-root tests for each cross-section units. Under the null hypothesis of a unit root for all cross-section units, the test statistic is non-parametric and has a chi-square distribution with $2 \mathrm{~N}$ degrees of freedom asymptotically:

$$
-2 \sum_{i=1}^{N} \log \left(\pi_{i}\right) \sim \chi_{2 N}^{2} .
$$

The Maddala and $\mathrm{Wu}^{45}$ test has the advantage over the IPS test, because it does not depend on different lag lengths in the individual ADF regression.

Based on the $p$-values from individual unit-root tests, Choi ${ }^{44}$ demonstrates that:

$$
Z=\frac{1}{\sqrt{N}} \sum_{i=1}^{N} \Phi^{-1}\left(\pi_{i}\right) \sim N(0,1),
$$

where $\Phi^{-1}$ is the inverse of the normal cumulative distribution function. This paper uses the above panel unit-root tests to determine whether the panel data in our models are non-stationary.

\footnotetext{
${ }^{42}$ Levin et al. (2002).

${ }^{43} \mathrm{Im}$ et al. (2003).

${ }^{44}$ Choi (2001).

${ }^{45}$ Maddala and Wu (1999).

${ }^{46}$ Fisher (1932).
} 


\section{Panel cointegration tests}

Pedroni ${ }^{47}$ considers the following panel data regression:

$$
y_{i t}=\alpha_{i}+\delta_{i} t+X_{i t} \beta_{i}+e_{i t}
$$

where $y_{i t}$ is an observable scalar (proxied for life insurance markets), $\mathbf{X}_{i t}$ is a $(1 \times m)$ vector of observable variables (globalisation index), $\alpha_{i}$ captures unit-specific fixed effects, $\delta_{i}$ is a country-specific deterministic trend effect designed to capture the common disturbances across countries in the panel, and $e_{i t}$ is the error term. Pedroni ${ }^{47}$ develops asymptotic and finite-sample properties of the test statistic to examine the null hypothesis of no cointegration in the panel. The vector of slope coefficients is allowed to vary across countries in the panel, suggesting that the cointegrating vector may be heterogeneous across countries.

Pedroni ${ }^{48}$ proposes two types of panel cointegration tests. One is based on the within-dimension approach (panel test), including four test statistics: the panel $v$-statistic, the panel $r$-statistic, the panel PP-statistic, and the panel ADF-statistic; the other is based on the between-dimension approach (group test), including three statistics: the group $r$-statistic, the group PP-statistic and the group ADF-statistic. These statistics are calculated by simply averaging the separately estimated coefficients for each member. All test statistics are distributed as standard normal asymptotically. The panel $v$-statistic is related to a one-sided test in which large positive values reject the null of no cointegration. The remaining statistics diverge to negative infinitely, indicating that large negative values reject the null. The critical values are tabulated in Pedroni's study. ${ }^{49}$

\section{Fully modified OLS approach}

Pedroni ${ }^{50}$ proposes a group-mean panel fully modified OLS (FMOLS) estimation for heterogeneous cointegrating panels. Considering the cointegration system for a panel consisting of $i=1, \ldots, N$ countries,

$$
\begin{aligned}
& y_{i t}=\alpha_{i}+\beta x_{i t}+u_{i t} \\
& x_{i t}=x_{i t-1}+\varepsilon_{i t},
\end{aligned}
$$

where the vector error process $\xi_{i t}=\left(u_{i t}, \varepsilon_{i t}\right)^{\prime}$ is stationary with asymptotic covariance matrix $\boldsymbol{\Omega}_{i}$. The asymptotic covariance matrix $\boldsymbol{\Omega}_{i}$ varies across individual members and is given by $\boldsymbol{\Omega}_{i} \equiv \lim _{T \rightarrow \infty} E\left[T^{-1}\left(\sum_{t=1}^{T} \xi_{i t}\right)\left(\sum_{t=1}^{T} \xi_{i t}^{\prime}\right)\right]$ which can be decomposed as $\boldsymbol{\Omega}_{i}=\Omega_{i}^{0}+\Gamma_{i}+\Gamma_{i}^{\prime}$, where $\Omega_{i}^{0}$ denotes the contemporaneous covariance and $\Gamma_{i}$ is a weighted sum of autocovariances.

\footnotetext{
${ }^{47}$ Pedroni (2004).

48 Pedroni (1999, 2004).

${ }^{49}$ Pedroni (1999).

${ }^{50}$ Pedroni (2001).
} 
Based on Pedroni, ${ }^{3}$ the between-dimension, group-mean panel FMOLS estimator can be given as

$$
\hat{\beta}_{G F M}^{*}=N^{-1} \sum_{i=1}^{N}\left(\sum_{t=1}^{T}\left(x_{i t}-\bar{x}_{i}\right)^{2}\right)^{-1}\left(\sum_{t=1}^{T}\left(x_{i t}-\bar{x}_{i}\right) y_{i t}^{*}-T \hat{\gamma}_{i}\right),
$$

where $y_{i t}^{*}=\left(y_{i t}-\bar{y}_{i}\right)-\left(\hat{\Omega}_{21 i}\right) /\left(\hat{\Omega}_{22 i}\right) \Delta x_{i t}$ and $\hat{\gamma}_{i} \equiv \hat{\Gamma}_{21 i}+\hat{\Omega}_{21 i}^{0}-\left(\hat{\Omega}_{21 i}\right) /\left(\hat{\Omega}_{22 i}\right)\left(\hat{\Gamma}_{22 i}+\hat{\Omega}_{22 i}^{0}\right)$. The associated $t$-statistic can be constructed as

$$
t_{\hat{\beta}_{G F M}^{*}}=N^{-\frac{1}{2}} \sum_{i=1}^{N}\left(\hat{\beta}_{F M, i}^{*}-\beta\right)\left(\hat{\Omega}_{11 i}^{-1} \sum_{t=1}^{T}\left(x_{i t}-\bar{x}_{i}\right)^{2}\right)^{\frac{1}{2}},
$$

where $\hat{\beta}_{F M, i}^{*}$ is the conventional FMOLS estimator applied to the $i^{\text {th }}$ member of the panel. The asymptotic distribution of $t$-statistic is standard normal as $T \rightarrow \infty$ and $N \rightarrow \infty$.

\section{Panel cointegration test with structural breaks}

Our study applies the panel cointegration test with structural breaks provided by Westerlund. ${ }^{4}$ The data-generating process for the dependent variable $Y_{i t}$ is given by a system of equations as follows:

$$
\begin{gathered}
Y_{i t}=\gamma_{i j} S B_{i t}+\beta_{i} X_{i, t}+e_{i, t}, \quad i=1, \ldots, N, \quad t=1, \ldots, T, \\
e_{i t}=r_{i t}+u_{i t}, \\
r_{i t}=r_{i t-1}+\phi_{i} u_{i t},
\end{gathered}
$$

where $X_{i, t}$ individually indicates the globalisation variables, GLOB, ECO, POL and SOC; $S B_{i t}$ implies the deterministic components that include the specific intercept and the factors of structural breaks, and the index $j=1, \ldots, M_{i}$ denotes the break points. The locations of the structural breaks are given as a fixed fraction $\lambda_{i j} \in(0,1)$ of $T$ such that $T_{i j}=\left[\lambda_{i j} T\right]$ and $\lambda_{i j-1}<\lambda_{i j}$.

To determine whether the long-run relationship under multiple structural breaks exists, the null hypothesis of this model suggests that all countries in the panel are cointegrated, and the alternative is formulated as there being at least some countries for which cointegration does not hold:

$\mathrm{H}_{0}: \phi_{i}=0$ for all $i=1, \ldots, N$.

$\mathrm{H}_{1}: \phi_{i} \neq 0$ for $i=1, \ldots, N_{1}$ and $\phi_{i}=0$ for $i=N_{1}+1, \ldots, N$.

According to the model developed by Westerlund, ${ }^{4}$ the panel Lagrange multiplier test statistic is defined as follows:

$$
Z(M) \equiv \frac{1}{N} \sum_{i=1}^{N} \sum_{j=1}^{M_{i}+1} \sum_{t=T_{i j-1}+1}^{T_{i j}}\left(T_{i j}-T_{i j-1}\right)^{-2} \hat{\sigma}_{i}^{-2} S_{i, t}^{2}
$$


where $S_{i, t}=\sum_{k=T_{i j-1}+1}^{t} \hat{e}_{i k}^{*}$ and $\hat{e}_{i, t}^{*}$ is the regression residual obtained by using any efficient estimator of the cointegration vector. The test is general enough to allow for endogenous regressors, serial correlations and an unknown number of breaks that may be located at different dates for different individuals. Westerlund ${ }^{4}$ shows that $Z(M)$ reaches the following sequential limit as $T \rightarrow \infty$ and then $N \rightarrow \infty$ under the null hypothesis:

$$
\frac{\sqrt{N}(Z(M)-E(Z(M)))}{\sqrt{\operatorname{var} Z(M))}} \Rightarrow N(0,1),
$$

where the respective mean and variance adjustment terms $E(Z(M))$ and $\operatorname{var} Z(M)$ are defined in Westerlund's study. ${ }^{4}$ For the estimation of the number of breaks and their locations, Westerlund suggests using the Bai and Perron ${ }^{51}$ procedure.

\section{Empirical results}

\section{Preliminary statistics}

Table 1 reports the average as well as the rank of globalisation indices and life insurance penetration. The results indicate that countries with higher globalisation have higher life insurance penetration. As can be seen, most countries with an overall globalisation index (GLOB) above the median country (Greece) also have life insurance penetration above the median country (Malaysia), except for Austria, Spain, New Zealand and Italy. Hence, globalisation should have some positive association with life insurance development.

Table 2 shows the estimated parameters of Eq. (1) for the S-curve model, all of which are significant at the significance level of 1 per cent, based on the logistic function of Enz. ${ }^{7}$ All parameters are significantly different from zero; $C_{3}$ is less than 1 , which implies penetration increases with real GDP per capita. According to these estimates, we calculate the world life insurance growth curve and then subtract it from actual penetrations of the country to obtain the deviation, in absolute terms (DEV).

Figure 2 plots the relationships between the deviation of international life insurance markets (vertical axis) and the composite KOF globalisation index as well as subindices on economic, social and political aspects in year 2007. The scatterplots reveal mixed appearances and some interesting phenomena emerge. The relation between the composite index and the deviation reveals a slightly inverted U-shape, indicating that the relationship between globalisation and the deviation might be non-linear. The social index plot has a similar pattern. Furthermore, the economic index plot scatters evenly, and the low deviation somewhat concentrates around higher political globalisation.

Some conjectures emerge for the plots above. For life insurance consumption, the economic factors, for example income level, should have the most direct effect. Hence, a reduction in the difference of income level may have some impact on decreasing the divergence of life insurance development across countries. However, socio-cultural

\footnotetext{
${ }^{51}$ Bai and Perron (2003).
} 
The Geneva Papers on Risk and Insurance-Issues and Practice 138

Table 1 Average and rank of globalisation index and life insurance penetration (1979-2007)

\begin{tabular}{|c|c|c|c|c|c|c|c|}
\hline Country & $E C O$ & $S O C$ & $P O L$ & $G L O B$ & Rank & $I N S$ & Rank \\
\hline Netherlands & 87.96 & 82.78 & 93.09 & 87.21 & 1 & 4.02 & 8 \\
\hline Belgium & 87.57 & 78.61 & 94.62 & 85.82 & 2 & 3.02 & 13 \\
\hline Switzerland & 81.89 & 87.76 & 85.81 & 85.13 & 3 & 5.48 & 5 \\
\hline Canada & 74.98 & 87.04 & 92.40 & 83.93 & 4 & 2.67 & 15 \\
\hline Sweden & 78.46 & 80.96 & 95.35 & 83.57 & 5 & 3.29 & 11 \\
\hline Austria & 71.69 & 85.95 & 93.23 & 82.50 & 6 & 1.85 & 22 \\
\hline Singapore & 94.21 & 87.39 & 55.73 & 82.13 & 7 & 2.99 & 14 \\
\hline Denmark & 75.52 & 79.36 & 92.44 & 81.16 & 8 & 3.07 & 12 \\
\hline Norway & 75.65 & 75.50 & 89.71 & 79.04 & 9 & 2.06 & 18 \\
\hline France & 66.21 & 75.90 & 96.75 & 77.46 & 10 & 4.06 & 7 \\
\hline Australia & 65.97 & 79.96 & 87.38 & 76.65 & 11 & 3.63 & 9 \\
\hline Finland & 71.98 & 68.71 & 89.86 & 75.10 & 12 & 4.93 & 6 \\
\hline United Kingdom & 74.57 & 77.38 & 71.41 & 74.88 & 13 & 7.13 & 2 \\
\hline Spain & 69.04 & 70.07 & 85.57 & 73.49 & 14 & 1.64 & 24 \\
\hline United States & 61.21 & 71.69 & 91.57 & 72.72 & 15 & 3.51 & 10 \\
\hline New Zealand & 70.53 & 69.97 & 74.20 & 71.21 & 16 & 1.83 & 23 \\
\hline Germany & 62.64 & 77.14 & 73.14 & 70.84 & 17 & 2.62 & 16 \\
\hline Portugal & 72.34 & 59.65 & 79.99 & 69.29 & 18 & 1.96 & 19 \\
\hline Italy & 59.65 & 61.00 & 93.57 & 68.49 & 19 & 1.87 & 21 \\
\hline Greece & 63.22 & 52.70 & 79.08 & 63.03 & 20 & 0.63 & 29 \\
\hline Malaysia & 70.06 & 52.32 & 65.88 & 62.15 & 21 & 1.92 & 20 \\
\hline Israel & 68.20 & 55.81 & 56.06 & 60.42 & 22 & 2.09 & 17 \\
\hline Mexico & 55.53 & 44.86 & 69.92 & 54.92 & 23 & 0.50 & 31 \\
\hline Argentina & 47.40 & 40.74 & 87.23 & 54.58 & 24 & 0.42 & 33 \\
\hline Japan & 45.03 & 45.55 & 77.66 & 53.23 & 25 & 7.12 & 3 \\
\hline Tunisia & 50.93 & 38.09 & 77.63 & 52.50 & 26 & 0.12 & 38 \\
\hline Venezuela & 47.63 & 41.72 & 71.98 & 51.31 & 27 & 0.15 & 37 \\
\hline Brazil & 47.76 & 34.74 & 80.81 & 50.82 & 28 & 0.48 & 32 \\
\hline South Korea & 45.79 & 41.82 & 65.88 & 49.18 & 29 & 6.93 & 4 \\
\hline South Africa & 58.09 & 36.08 & 50.79 & 47.76 & 30 & 9.10 & 1 \\
\hline Egypt & 41.39 & 31.57 & 81.48 & 47.42 & 31 & 0.19 & 36 \\
\hline Philippines & 48.94 & 34.15 & 65.69 & 47.31 & 32 & 0.84 & 27 \\
\hline Colombia & 43.02 & 39.59 & 64.54 & 46.97 & 33 & 0.41 & 34 \\
\hline Thailand & 47.23 & 35.20 & 63.36 & 46.52 & 34 & 1.11 & 26 \\
\hline Morocco & 40.87 & 34.61 & 71.27 & 45.90 & 35 & 0.52 & 30 \\
\hline Indonesia & 46.23 & 20.68 & 71.81 & 42.59 & 36 & 0.40 & 35 \\
\hline Algeria & 32.01 & 24.41 & 74.96 & 39.60 & 37 & 0.06 & 39 \\
\hline Kenya & 31.20 & 20.96 & 71.64 & 37.15 & 38 & 0.64 & 28 \\
\hline India & 25.26 & 17.15 & 80.21 & 35.59 & 39 & 1.43 & 25 \\
\hline
\end{tabular}

Notes: Countries are ranked by overall globalisation score (GLOB). INS is life insurance penetration.

or political factors may have some interference. For instance, Muslim-dominated countries with high-income levels such as the United Arab Emirates, Qatar and Kuwait have life insurance penetration below the global average since religious opposition to life insurance still remains in these countries. ${ }^{52}$ This implies that the

\footnotetext{
${ }^{52}$ Hussels et al. (2005).
} 
Table 2 Estimates of the logistic model

\begin{tabular}{|c|c|c|}
\hline & Coefficient & t-statistic \\
\hline$C_{1}$ & $12.74 * * *$ & 6.04 \\
\hline$C_{2}$ & $90.88 * * *$ & 8.97 \\
\hline$C_{3}$ & $0.92 * * *$ & 90.84 \\
\hline$R^{2}$ & \multicolumn{2}{|c|}{0.6233} \\
\hline Adjusted- $R^{2}$ & \multicolumn{2}{|c|}{0.6223} \\
\hline Number of observations & \multicolumn{2}{|c|}{1131} \\
\hline
\end{tabular}

Notes: Robust $t$-statistic is in parentheses.

*** indicates significance level of 1 per cent.
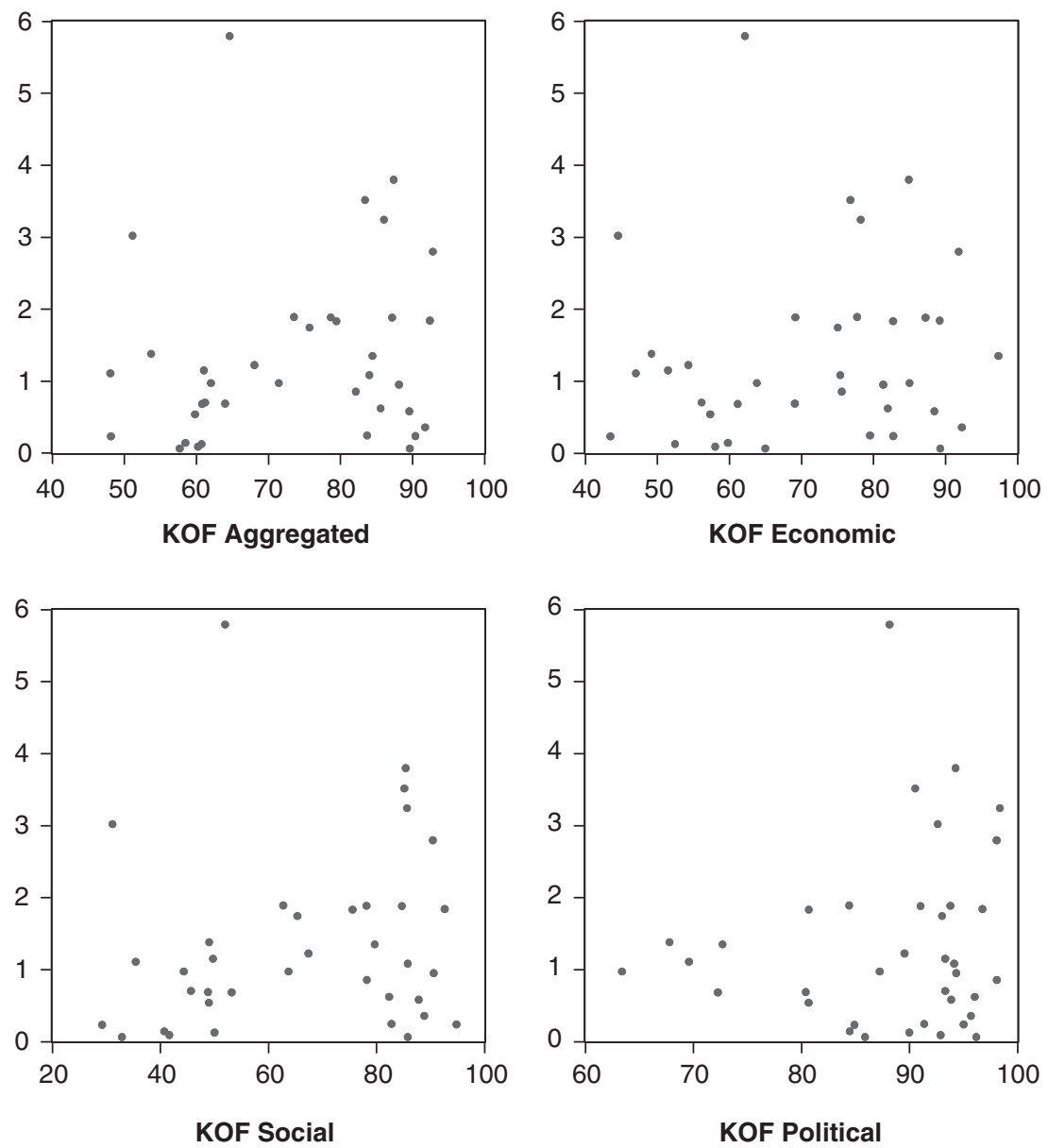

Figure 2. Cross-country correlation between globalisation and deviation, 2007.

Note: The vertical axis is the deviation of international life insurance markets. 
140

influence in socio-cultural aspects may neutralise the effect of economic aspects. Therefore, the interactive influence between alternative dimensions within the country complicates the impact of globalisation. As the KOF overall index of globalisation is derived from the three sub-indices, a non-linear pattern may result from the impact of the social index.

Socio-cultural aspects should be the most complicated dimension, which could be justified by Dreher ${ }^{9}$ who argues that the flow of information and ideas encompasses the hardest dimensions to pin down when evaluating globalisation and by Keohane and $\mathrm{Nye}^{53}$ who contend that these aspects consist of the most pervasive form of globalism. Put another way, the non-linear pattern above may reflect the sophisticated interactive relation among sub-dimensions of globalisation. Steger ${ }^{54}$ notes that globalisation is "a multidimensional set of social processes that create, multiply, stretch and intensify worldwide social interdependencies and exchanges while at the same time fostering in people a growing awareness of deepening connections between the local and the distant". We investigate the interactive effect between sub-indices of globalisation in a later section.

\section{Panel unit-root test results}

To avoid spurious regressions, the first necessary step is to test whether the data is stationary or not. Table 3 presents the results from the panel unit-root tests at the 1 per cent significance level based on the studies of Levin et al. ${ }^{42}$ and Im et al. ${ }^{43}$ the ADFFisher Chi-square, and the PP-Fisher Chi-square. All statistics strongly show that the six variables-INS, DEV, GLOB, ECO, SOC and POL - have a unit root, implying that all variables follow the I(1) process at 1 per cent significance levels. To determine whether there exists a long-run relationship between the convergence of international life insurance penetrations and globalisation, the panel cointegration test is performed.

\section{Globalisation and the development of life insurance markets}

Table 4 reports the panel cointegration test results between globalisation and life insurance penetration (INS). At first glance, the overall test statistics show a weak relationship between globalisation and life insurance development. GLOB and ECO have significant coefficients on two ADF-type tests and SOC has one above the 10 per cent significance level, but no statistic is significant on POL. The relationship is also weak as the three sub-indices are incorporated together as independent variables (denoted as EPS), possibly due to the offsetting effect among sub-indices. The results indicate that globalisation in the long run is correlated with life insurance development and that among the three sub-indices, economic globalisation has the most significant influence on life insurance development, while the impact of political globalisation is the weakest. We analyse how the long-run relationship evolves through FMOLS estimation based on the significance of two ADF-type tests (Models 1 and 2 of

\footnotetext{
${ }^{53}$ Keohane and Nye (2000).

${ }^{54}$ Steger (2004).
} 
Table 3 Panel unit-root test results

\begin{tabular}{|c|c|c|c|c|c|c|c|c|}
\hline Method & Variables & INS & $D E V$ & $G L O B$ & $E C O$ & $S O C$ & $P O L$ & $E D$ \\
\hline \multirow[t]{3}{*}{ LLC (2002) } & Level & $\begin{array}{c}1.92 \\
(0.97)\end{array}$ & $\begin{array}{c}0.51 \\
(0.70)\end{array}$ & $\begin{array}{l}1.75 \\
(0.96)\end{array}$ & $\begin{array}{c}1.30 \\
(0.90)\end{array}$ & $\begin{array}{c}3.00 \\
(1.00)\end{array}$ & $\begin{array}{c}-0.38 \\
(0.35)\end{array}$ & $\begin{array}{c}4.97 \\
(1.00)\end{array}$ \\
\hline & $\begin{array}{l}\text { First } \\
\text { difference }\end{array}$ & $-17.83^{* * *}$ & $-16.94 * * *$ & $-8.84 * * *$ & $-15.89 * * *$ & $-12.35^{* * *}$ & $-13.77 * * *$ & $-9.64 * * *$ \\
\hline & & $(0.00)$ & $(0.00)$ & $(0.00)$ & $(0.00)$ & $(0.00)$ & $(0.00)$ & $(0.00)$ \\
\hline \multirow{4}{*}{$\begin{array}{l}\text { IPS (2003) } \\
\text { W-stat }\end{array}$} & Level & 3.44 & 2.56 & 2.83 & 2.77 & 3.48 & 0.26 & 5.63 \\
\hline & & (1.00) & (0.99) & $(1.00)$ & $(1.00)$ & $(1.00)$ & $(0.60)$ & $(1.00)$ \\
\hline & $\begin{array}{l}\text { First } \\
\text { difference }\end{array}$ & $-14.30 * * *$ & $-15.38 * * *$ & $-8.08 * * *$ & $-14.09^{* * *}$ & $-8.27 * * *$ & $-13.63^{* * *}$ & $-9.82 * * *$ \\
\hline & & $(0.00)$ & $(0.00)$ & $(0.00)$ & $(0.00)$ & $(0.00)$ & $(0.00)$ & $(0.00)$ \\
\hline \multirow{4}{*}{$\begin{array}{l}\text { ADF-Fisher } \\
\text { chi-square }\end{array}$} & Level & 56.52 & 74.06 & 48.32 & 42.24 & 42.03 & 67.74 & 31.77 \\
\hline & & $(0.97)$ & $(0.61)$ & $(1.00)$ & $(1.00)$ & $(1.00)$ & $(0.79)$ & (1.00) \\
\hline & $\begin{array}{l}\text { First } \\
\text { difference }\end{array}$ & $401.88^{* * *}$ & $410.57 * * *$ & $243.35 * * *$ & $346.42 * * *$ & $345.10^{* * *}$ & $330.63^{* * *}$ & $237.05 * * *$ \\
\hline & & $(0.00)$ & $(0.00)$ & $(0.00)$ & $(0.00)$ & $(0.00)$ & $(0.00)$ & $(0.00)$ \\
\hline \multirow{4}{*}{$\begin{array}{l}\text { PP-Fisher } \\
\text { chi-square }\end{array}$} & Level & 59.53 & 96.88 & 45.95 & 78.78 & 67.03 & 70.32 & 40.96 \\
\hline & & $(0.94)$ & $(0.07)$ & $(1.00)$ & $(0.45)$ & $(0.81)$ & $(0.72)$ & $(1.00)$ \\
\hline & $\begin{array}{l}\text { First } \\
\text { difference }\end{array}$ & $673.55^{* * *}$ & $766.97 * * *$ & $507.69 * * *$ & $1000.55^{* * *}$ & $518.98 * * *$ & $697.63 * * *$ & $372.69 * * *$ \\
\hline & & $(0.00)$ & $(0.00)$ & $(0.00)$ & $(0.00)$ & $(0.00)$ & $(0.00)$ & $(0.00)$ \\
\hline
\end{tabular}

Notes: All tests test the null hypothesis of unit root. Fisher-type tests are computed under an asymptotic chisquare distribution, and other tests assume asymptotic normality. $p$-values are in parentheses. All variables are in natural logarithms. DEV is a measure of the deviation level of a country's life insurance penetration relative to the world's average penetrations.

$* * *$ indicates significance level of 1 per cent.

Table 4). ${ }^{55}$ As Table 5 shows, both GLOB and ECO exert a significant positive effect on the development of life insurance markets. Hence, in the long run the development of life insurance rises with the increase of globalisation, and the economic factor has a more direct effect than social and political dimensions. ${ }^{56}$

\section{Globalisation and the convergence of international life insurance markets}

Table 6 reports the panel cointegration test results for the deviation of international life insurance markets (DEV) and globalisation. All test statistics for the overall

55 Pedroni (1999) shows that the panel ADF and group ADF tests have better small-sample properties than other tests and thus are more reliable. Moreover, in their simulation studies, Wagner and Hlouskova (2010) also document that Pedroni's tests, applying the ADF principle, perform best and are least affected by short-run cross-sectional correlation or cross-unit cointegration.

${ }^{56}$ We perform the differenced generalised method of moments (GMM) estimation to examine the effects of SOC and POL. The results, available upon request, show that social globalisation has a significantly positive effect on life insurance development, but the effect of political globalisation is not significant. 
The Geneva Papers on Risk and Insurance-Issues and Practice

142

Table 4 Pedroni's (1999) cointegration test results - globalisation and life insurance development

\begin{tabular}{|c|c|c|c|c|c|}
\hline Model & 1 & 2 & 3 & 4 & 5 \\
\hline Test statistic & $G L O B$ & $E C O$ & $S O C$ & $P O L$ & $E P S$ \\
\hline \multirow[t]{2}{*}{ Panel variance } & $1.57^{*}$ & 0.05 & $2.62 * * *$ & -2.41 & -0.57 \\
\hline & $(0.06)$ & $(0.48)$ & $(0.00)$ & (0.99) & $(0.72)$ \\
\hline \multirow[t]{2}{*}{ Panel $\rho$} & -0.78 & -0.55 & -0.56 & 2.02 & 2.37 \\
\hline & $(0.22)$ & $(0.29)$ & $(0.29)$ & $(0.98)$ & $(0.99)$ \\
\hline \multirow[t]{2}{*}{ Panel PP } & -1.09 & -1.25 & -0.25 & 1.14 & 1.26 \\
\hline & $(0.14)$ & $(0.11)$ & $(0.40)$ & $(0.87)$ & $(0.90)$ \\
\hline \multirow[t]{2}{*}{ Panel ADF } & $-2.27 * *$ & $-3.35^{* * *}$ & -0.81 & 1.18 & -1.04 \\
\hline & $(0.01)$ & $(0.00)$ & $(0.21)$ & $(0.88)$ & $(0.15)$ \\
\hline \multirow[t]{2}{*}{ Group $\rho$} & 0.09 & -0.89 & 0.68 & 2.93 & 2.62 \\
\hline & $(0.54)$ & $(0.19)$ & $(0.75)$ & $(1.00)$ & $(1.00)$ \\
\hline \multirow[t]{2}{*}{ Group PP } & -0.86 & $-2.05^{* *}$ & -0.31 & 2.24 & -0.42 \\
\hline & $(0.20)$ & $(0.02)$ & $(0.38)$ & $(0.99)$ & $(0.34)$ \\
\hline \multirow[t]{2}{*}{ Group ADF } & $-1.60^{*}$ & $-3.22 * * *$ & $-1.55^{*}$ & 2.25 & $-1.99 * *$ \\
\hline & $(0.05)$ & $(0.00)$ & $(0.06)$ & $(0.99)$ & $(0.02)$ \\
\hline
\end{tabular}

Notes: EPS denotes joint consideration of economic, social and political globalisations. The null hypothesis is that the variables are not cointegrated. All statistics are asymptotically distributed as standard normal. $p$-values are in parentheses.

$* * *, * *$ and $*$ indicate significance levels of 1 per cent, 5 per cent and 10 per cent, respectively.

Table 5 FMOLS estimations for the development of international life insurance markets

\begin{tabular}{lcc}
\hline Model & 1 & 2 \\
\hline Panel coefficient & $G L O B$ & ECO \\
\hline & $\begin{array}{c}1.65^{* * *} \\
(43.35)\end{array}$ & $1.31^{* * * *}$ \\
& $(41.52)$ \\
\hline
\end{tabular}

Notes: Dependent variable is life insurance penetration (INS). $t$-statistics are in parentheses.

*** indicates significance level of 1 per cent.

globalisation index reject the null hypothesis of no cointegration at the 10 per cent significance level at least. The evidence is slightly weak when we consider the subindices of globalisation. Six out of the seven statistics, except for the group $\rho$ statistic, significantly reject the null hypothesis of no cointegration relationship between the deviation of life insurance markets and economic and social globalisation above the 5 per cent significance level, respectively. The cointegration relationship is even weaker when political globalisation is considered or when the three sub-indices are incorporated together in the cointegrating structure, with five and four statistics being statistically significant above the 10 per cent level, respectively.

Table 7 presents the FMOLS estimation results. The panel parameter for GLOB is significantly negative at the significance level of 1 per cent, with the coefficient estimator -0.64 indicating that a 1 per cent increase in the degree of globalisation leads to a 0.64 per cent decrease in the difference between one country's life insurance 
Table 6 Pedroni's cointegration test results - globalisation and deviation of life insurance markets

\begin{tabular}{|c|c|c|c|c|c|}
\hline Model & 1 & 2 & 3 & 4 & 5 \\
\hline Test statistic & $G L O B$ & $E C O$ & $S O C$ & $P O L$ & $E P S$ \\
\hline Panel variance & $\begin{array}{l}3.18^{* * *} \\
(0.00)\end{array}$ & $\begin{array}{l}2.68^{* * * *} \\
(0.00)\end{array}$ & $\begin{array}{l}2.27 * * \\
(0.01)\end{array}$ & $\begin{array}{l}1.65 * * \\
(0.05)\end{array}$ & $\begin{array}{c}0.92 \\
(0.18)\end{array}$ \\
\hline Panel $\rho$ & $\begin{array}{c}-5.16^{* * *} \\
(0.00)\end{array}$ & $\begin{array}{c}-5.04^{* * *} \\
(0.00)\end{array}$ & $\begin{array}{l}-4.77 * * * \\
(0.00)\end{array}$ & $\begin{array}{l}-3.05^{* * *} \\
(0.00)\end{array}$ & $\begin{array}{c}-1.12 \\
(0.13)\end{array}$ \\
\hline Panel PP & $\begin{array}{c}-4.87 * * * \\
(0.00)\end{array}$ & $\begin{array}{c}-4.87 * * * \\
(0.00)\end{array}$ & $\begin{array}{c}-4.57 * * * \\
(0.00)\end{array}$ & $\begin{array}{c}-3.50^{* * *} \\
(0.00)\end{array}$ & $\begin{array}{c}-3.66^{* * * *} \\
(0.00)\end{array}$ \\
\hline Panel ADF & $\begin{array}{c}-4.87 * * * \\
(0.00)\end{array}$ & $\begin{array}{c}-4.96^{* * *} \\
(0.00)\end{array}$ & $\begin{array}{c}-5.21^{* * *} \\
(0.00)\end{array}$ & $\begin{array}{c}-3.82^{* * *} \\
(0.00)\end{array}$ & $\begin{array}{c}-3.97 * * * \\
(0.00)\end{array}$ \\
\hline Group $\rho$ & $\begin{array}{c}-1.45^{*} \\
(0.07)\end{array}$ & $\begin{array}{c}-1.25 \\
(0.11)\end{array}$ & $\begin{array}{c}-0.91 \\
(0.18)\end{array}$ & $\begin{array}{c}0.22 \\
(0.59)\end{array}$ & $\begin{array}{c}1.88 \\
(0.97)\end{array}$ \\
\hline Group PP & $\begin{array}{c}-2.93^{* * * *} \\
(0.00)\end{array}$ & $\begin{array}{c}-2.76^{* * *} \\
(0.00)\end{array}$ & $\begin{array}{l}-2.70^{* * *} \\
(0.00)\end{array}$ & $\begin{array}{r}-1.12 \\
(0.13)\end{array}$ & $\begin{array}{c}-2.11 * * \\
(0.02)\end{array}$ \\
\hline Group ADF & $\begin{array}{c}-3.73 * * * \\
(0.00)\end{array}$ & $\begin{array}{c}-4.42^{* * *} \\
(0.00)\end{array}$ & $\begin{array}{c}-4.41^{* * *} \\
(0.00)\end{array}$ & $\begin{array}{r}-1.53^{*} \\
(0.06)\end{array}$ & $\begin{array}{c}-2.97 * * * \\
(0.00)\end{array}$ \\
\hline
\end{tabular}

Notes: The null hypothesis is that the variables are not cointegrated. All statistics are asymptotically distributed as standard normal. EPS denotes joint consideration of economic, social and political globalisation. $p$-values are in parentheses. All variables are in natural logarithms.

$* * *, * *$ and $*$ indicate significance levels of 1 per cent, 5 per cent and 10 per cent, respectively.

Table 7 FMOLS estimations for the effect of globalisation index on the deviation of international life insurance markets

\begin{tabular}{|c|c|c|c|c|c|}
\hline Model & 1 & 2 & 3 & 4 & 5 \\
\hline GLOB & $\begin{array}{l}-0.64 * * * \\
(-3.28)\end{array}$ & & & & \\
\hline ECO & & $\begin{array}{l}-0.52 * * * \\
(-3.66)\end{array}$ & & & $\begin{array}{c}-0.11 \\
(-0.76)\end{array}$ \\
\hline SOC & & & $\begin{array}{l}-0.49 * * * \\
(-4.92)\end{array}$ & & $\begin{array}{l}-0.42^{* * * *} \\
(-3.23)\end{array}$ \\
\hline POL & & & & $\begin{array}{c}-0.05 \\
(-0.35)\end{array}$ & $\begin{array}{l}-0.59 * * * \\
(-3.66)\end{array}$ \\
\hline
\end{tabular}

Notes: Dependent variable is the deviation between individual life insurance penetration and the world average (DEV). $t$-statistics are in parentheses. All variables are in natural logarithms.

$* * *$ indicates significance level of 1 per cent.

penetration and the world average. This suggests that the deviation among international life insurance markets diminishes with the evolution of globalisation or, put differently, that globalisation is helpful for the convergence of international life insurance markets in the long run.

To further examine the divergent effect of various dimensions of globalisation, we replicate the analysis with the sub-indices. As shown in Models 2-4 of Table 7, economic and social aspects have a significantly negative coefficient on the deviation 
144

of life insurance development at the 1 per cent level, but the coefficient of political globalisation is not significant. This implies that globalisation through economic and social dimensions should exert an impact on the convergence of life insurance markets across countries. The coefficient estimator in economic globalisation is -0.52 , indicating that a 1 per cent increase in economic globalisation leads to a 0.52 per cent decrease in the divergence of the world life insurance market as compared to 0.49 per cent in social globalisation. The largest coefficient in absolute terms suggests that economic globalisation has a more significant effect on the convergence of the world life insurance market when alternative globalisation is considered individually. This may be because economic conditions, for example, income level or the degree of development, exert a more direct effect on life insurance consumption compared to other factors.

As economic, social and political dimensions within the system may interact with each other, we examine the joint effect by analysing the model with the three sub-indices as independent variables. As Model 5 in Table 7 shows, social globalisation still has a significantly negative coefficient on the deviation of international life insurance markets at the significance level of 1 per cent. However, the effect of economic factor is no longer significant and political globalisation now has a significant effect. This implies that the effect in alternative dimensions may offset one another. We further perform an interactive analysis to reveal the interrelationship between them more clearly.

\section{The interactive effect of different dimensions of globalisation}

Beck and Webb, ${ }^{57}$ Brown et al.,${ }^{58}$ and Chen et al. ${ }^{59}$ note that economic, cultural and political dimensions of globalisation potentially reinforce each other. To assess the interdependence, we perform FMOLS technique on the sub-indices of globalisation and various interaction terms. ${ }^{60}$ Doing so allows us to evaluate the direct effect as well as the indirect effect from alternative indices, both of which consist of the total effect.

As shown in Table 8, three findings are observed. First, the direct effect of social globalisation is significantly negative, but the indirect effect from the other two subindices is not significant, and the total effect is negative. As Models 3 and 4 presented, an increase in social globalisation results in a decrease in the deviation of international life insurance markets at the significance level of 5 per cent, but the interaction terms $(\mathrm{ECO} \times \mathrm{SOC}$ and $\mathrm{SOC} \times \mathrm{POL})$ enter insignificantly. This means social globalisation uniformly exerts a promotion effect on the convergence of the world life insurance markets, and the remainder two dimensions have no significance influence on such an important role played by social globalisation.

Second, when incorporating the influence of social globalisation, the effects of economic and political globalisations are positive, but the effect is tempered by social

\footnotetext{
${ }^{57}$ Beck and Webb (2003).

58 Brown et al. (2000).

${ }^{59}$ Chen et al. (2011).

${ }^{60}$ We also perform the panel cointegration test before the FMOLS estimation of the interactive effect. The results reject the null hypothesis of no cointegration as well.
} 
Table 8 FMOLS estimations for interactive effects between different types of globalisation

\begin{tabular}{lcccccc}
\hline Model & 1 & 2 & 3 & 4 & 5 & 6 \\
\hline ECO & 0.17 & -0.37 & & & & \\
SOC & $(0.77)$ & $(-1.49)$ & $-0.45^{* *}$ & $-0.72^{* *}$ & & \\
POL & & & $(-2.15)$ & $(-2.56)$ & 0.19 & $0.53^{* *}$ \\
ECO $\times$ SOC & $-0.13^{* * *}$ & & -0.03 & & $(0.88)$ & $(2.24)$ \\
ECO $\times$ POL & $(-3.70)$ & -0.03 & $(-0.68)$ & & & \\
SOC $\times$ POL & & $(-0.81)$ & & & -0.06 & \\
& & & & -0.01 & & $-0.08^{* * *}$ \\
\hline
\end{tabular}

Notes: Dependent variable is the deviation between individual life insurance penetration and the world average (DEV). $t$-statistics are in parentheses. All variables are in natural logarithms.

$* * *$ and $* *$ indicate significance level of 1 per cent and 5 per cent, respectively.

globalisation, as shown in Models 1 and 6. This implies that social globalisation plays a moderating role on the influence of economic and political globalisations on the convergence of the world life insurance markets.

Third, the effects of economic and political globalisations are not clearly identified when the indirect effects from the alternative dimension are considered, as shown in Models 2 and 5. The direct effect of economic globalisation is negative and the indirect effect from the political dimension is negative as well, with a negative total effect. The direct effect of political globalisation is positive and the indirect effect from the economic dimension is negative, with a positive total effect. Nevertheless, none of their coefficients is statistically significant.

\section{Does the globalisation proxy for economic development?}

Some suspicion may emerge that it is economic development but not globalisation that promotes the development of life insurance markets because of the close association between globalisation and economic development, that is, globalisation index is only a proxy of economic development. To address this issue, we replicate the analyses above by controlling for economic development, proxied by GDP per capita (ED), to see if the effect of the globalisation index alters. As Table 9 shows, the findings on globalisation indices are qualitatively similar. ${ }^{61}$ The overall index as well as sub-dimensions of globalisation is significantly and positively correlated with life insurance development at the 1 per cent significance level even after the inclusion of the measure of economic development, as shown in Panel A of Table 9. Panel B shows

\footnotetext{
${ }^{61}$ We perform the panel cointegration test first and the null hypothesis of no cointegration is rejected in all cases. The results on panel cointegration test are not reported in order to save space.
} 
Table 9 The impact of economic development on the relationship between globalisation and life insurance markets

\begin{tabular}{|c|c|c|c|c|c|}
\hline Model & 1 & 2 & 3 & 4 & 5 \\
\hline \multicolumn{6}{|c|}{ Panel A. Dependent variable-life insurance penetration (INS) } \\
\hline GLOB & $\begin{array}{l}0.69^{* * *} \\
(10.30)\end{array}$ & & & & \\
\hline $\mathrm{ECO}$ & & $\begin{array}{l}0.44 * * * \\
(8.67)\end{array}$ & & & $\begin{array}{l}0.43 * * * \\
(7.89)\end{array}$ \\
\hline $\mathrm{SOC}$ & & & $\begin{array}{l}0.45^{* * *} \\
(10.58)\end{array}$ & & $\begin{array}{l}0.27 * * * \\
(6.11)\end{array}$ \\
\hline POL & & & & $\begin{array}{l}0.27 * * * \\
(3.97)\end{array}$ & $\begin{array}{l}-0.19^{* * *} \\
(-3.64)\end{array}$ \\
\hline ED & $\begin{array}{l}0.67 * * * \\
(8.85)\end{array}$ & $\begin{array}{l}0.73^{* * *} \\
(12.72)\end{array}$ & $\begin{array}{l}0.77 * * * \\
(12.76)\end{array}$ & $\begin{array}{l}1.55^{* * *} \\
(31.35)\end{array}$ & $\begin{array}{l}0.62 * * * \\
(10.24)\end{array}$ \\
\hline
\end{tabular}

Panel B. Dependent variable - deviation between individual life insurance penetration and the world average (DEV)

\begin{tabular}{|c|c|c|c|c|c|}
\hline GLOB & $\begin{array}{c}-0.33^{*} \\
(-1.76)\end{array}$ & & & & \\
\hline ECO & & $\begin{array}{c}-0.18 \\
(-1.29)\end{array}$ & & & $\begin{array}{c}-0.18 \\
(-1.25)\end{array}$ \\
\hline SOC & & & $\begin{array}{l}-0.43^{* * *} \\
(-4.17)\end{array}$ & & $\begin{array}{l}-0.22 * \\
(-1.79)\end{array}$ \\
\hline POL & & & & $\begin{array}{c}-0.04 \\
(-0.27)\end{array}$ & $\begin{array}{l}-0.54 * * * \\
(-3.54)\end{array}$ \\
\hline ED & $\begin{array}{l}0.42^{* * *} \\
(3.12)\end{array}$ & $\begin{array}{c}0.14 \\
(1.02)\end{array}$ & $\begin{array}{l}0.50 * * * \\
(3.65)\end{array}$ & $\begin{array}{l}0.48^{* * *} \\
(3.47)\end{array}$ & $\begin{array}{c}0.21 \\
(1.43)\end{array}$ \\
\hline
\end{tabular}

Panel C. Dependent variable - deviation between individual life insurance penetration and the world average (DEV)

\begin{tabular}{|c|c|c|c|c|}
\hline GLOB & $\begin{array}{l}-1.11 * * * \\
(-4.56)\end{array}$ & & & \\
\hline $\mathrm{ECO}$ & & $\begin{array}{l}-0.80 * * * \\
(-3.72)\end{array}$ & & \\
\hline SOC & & & $\begin{array}{l}-1.55^{* * *} \\
(-8.00)\end{array}$ & \\
\hline POL & & & & $\begin{array}{c}-0.48 * \\
(-1.86)\end{array}$ \\
\hline $\mathrm{GLOB} \times \mathrm{ED}$ & $\begin{array}{l}0.14^{* * * *} \\
(4.39)\end{array}$ & & & \\
\hline $\mathrm{ECO} \times \mathrm{ED}$ & & $\begin{array}{l}0.06^{* *} \\
(2.12)\end{array}$ & & \\
\hline $\mathrm{SOC} \times \mathrm{ED}$ & & & $\begin{array}{l}0.17^{* * * *} \\
(5.95)\end{array}$ & \\
\hline $\mathrm{POL} \times \mathrm{ED}$ & & & & $\begin{array}{l}0.14 * * * \\
(4.44)\end{array}$ \\
\hline
\end{tabular}

Notes: $t$-statistics are in parentheses. ED is a proxy of economic development. All variables are in natural logarithms except life insurance penetration (INS).

*** and * indicate significance levels of 1 per cent and 10 per cent, respectively. 
that the overall index and social dimension exert a positive impact in reducing the deviation of life insurance markets worldwide, although the effect of economic and political dimensions is insignificant. This finding somewhat corresponds to the results in Table 8 that social globalisation plays a more important role than do other two dimensions on reducing the deviation of international life insurance markets when we consider variables jointly.

Finally, the analysis of interaction effect between globalisation and economic development in Panel $\mathrm{C}$ shows that globalisation does matter in reducing the deviation of life insurance markets, but the impact is tempered by economic development, which is reflected in the positive coefficients on interaction terms. This suggests that globalisation still exerts a positive impact in reducing the difference of life insurance development across countries, even though some of the effect may be picked up by the progress of economic development.

\section{A reminder}

The concept of cointegration is used to capture the notion that non-stationary variables may nonetheless possess long-run equilibrium relationships and may thus exhibit a tendency to move together in the long run. ${ }^{62}$ Specifically, some reminders on the analysis above should come to mind. The cointegration analysis is an atheoretical approach, and the existence of the cointegration relationship cannot explain causal chains between variables. To be specific, if two variables are cointegrated, then one variable, say globalisation, may not impact another, say insurance development, directly but indirectly via its influence on other variables, for example, the demand for insurance or the price. Hence, we could interpret that globalisation alters the effect of some determinants on insurance development, which in turn influences the insurance market. Considering the examples of China and India noted above, globalisation or liberalisation brings about changes on factors impacting insurance development, for example, the introduction of innovative products stimulates the demand or the increased competition lowers the price, in turn affecting the insurance market. Whether a causal relationship exists between globalisation and life insurance development needs to be confirmed by more formal econometric approaches, which are beyond the focus of this paper.

\section{The effects of multiple structural breaks}

The analyses above indicate that globalisation does exert an influence in reducing the difference in the development of life insurance markets across countries. Since globalisation to some extent implies communication around the world, one may ask if the development of life insurance markets in one country corresponds to some trends in the world life insurance market. In this sub-section we further employ a panel cointegration technique with multiple structural breaks proposed by Westerlund ${ }^{4}$ to examine whether structural breaks exist and whether estimated break points in one country coincide with some specific periods in the world life insurance market.

\footnotetext{
${ }^{62}$ For a review, see Engle and Granger (1987).
} 
148

The reasons why we allow for structural breaks include the following. First, structural breaks are a common phenomenon that is usually observed in association with specific events such as political regime shifts, international conflicts, financial liberalisation and regulations. Second, considering structural breaks in empirical models allows us to obtain more detailed and meaningful information on the characteristics of globalisation. Third, an economic or financial system's instability may unfortunately be reflected in the estimated models, such that when the models are used for inference, they can induce misleading results. Due to the interdependent influence between various dimensions of globalisation as noted above, we include the three sub-indices in the analysis of panel cointegration with structural breaks.

If we take 10 per cent as the criterion of high growth rate, then, as noted in the introduction, the international life insurance market experiences high growth in the following periods: more than 30 per cent in 1985-1987 and 1993, and more than 10 per cent in 1988, 1990, 1994, 1995, 1999, 2004 and 2006. As Table 10 shows, life insurance markets in 24 out of the 39 countries experience structural changes. Most countries (18 out of 24) have a structural break during the two periods with special high growth rates above 30 per cent. The results show that overall the estimated structural break point in most countries has happened along with the rapid growth period in the world life insurance market, implying that the life insurance development in one country may not be isolated from the world market. Globalisation, perhaps, is the propeller behind

Table 10 Estimated structural breaks by Westerlund (2006)

\begin{tabular}{|c|c|c|c|c|c|c|c|}
\hline Country & $m$ & $T_{1}$ & $T_{2}$ & Country & $m$ & $T_{1}$ & $T_{2}$ \\
\hline Algeria & 1 & 1985 & & Korea, South & 2 & 1985 & 1992 \\
\hline Argentina & 2 & 1993 & 2000 & Malaysia & 2 & 1986 & 1993 \\
\hline Australia & 1 & 1993 & & Mexico & 1 & 1998 & \\
\hline Austria & 0 & & & Morocco & 0 & & \\
\hline Belgium & 2 & 1991 & 1998 & Netherlands & 2 & 1989 & 2000 \\
\hline Brazil & 1 & 2000 & & New Zealand & 2 & 1987 & 1994 \\
\hline Canada & 1 & 1990 & & Norway & 1 & 1994 & \\
\hline Colombia & 2 & 1991 & 1998 & Philippines & 2 & 1986 & 1993 \\
\hline Denmark & 2 & 1992 & 2000 & Portugal & 2 & 1986 & 1995 \\
\hline Egypt & 1 & 2000 & & Singapore & 2 & 1993 & 2000 \\
\hline Finland & 2 & 1985 & 1995 & South Africa & 2 & 1986 & 1999 \\
\hline France & 2 & 1990 & 1998 & Spain & 2 & 1988 & 1998 \\
\hline Germany & 1 & 1987 & & Sweden & 1 & 1994 & \\
\hline Greece & 1 & 2000 & & Switzerland & 2 & 1992 & 1999 \\
\hline India & 1 & 1989 & & Thailand & 1 & 1991 & \\
\hline Indonesia & 1 & 2000 & & Tunisia & 1 & 1985 & \\
\hline Israel & 2 & 1992 & 2000 & U.K. & 1 & 1985 & \\
\hline Italy & 2 & 1993 & 2000 & U.S. & 2 & 1985 & 1998 \\
\hline Japan & 2 & 1985 & 1992 & Venezuela & 2 & 1986 & 1998 \\
\hline Kenya & 2 & 1988 & 2000 & & & & \\
\hline
\end{tabular}

Notes: Dependent variable is the deviation of observed life insurance penetration from the world average penetration (DEV). Independent variables include the three sub-dimensions of globalisation-ECO, SOC and POL. $m$ denotes the estimated number of structural breaks. $T_{1}$ and $T_{2}$ represent the estimated first and second break points, respectively. 
the coincidence. The results also suggest that multiple structural changes in panel cointegration relationships are important and need to be taken into account under the specifications for the relationship between globalisation and life insurance markets. Hence, the specifications, comprising changing economic and financial events, do raise some important questions concerning the long-run relationships in these series.

\section{Implications}

Two implications arise from our findings above. First, the potential interdependence between globalisation in different dimensions should not be ignored. As Model 5 in Table 7 shows, economic globalisation becomes insignificant when we include political globalisation. This could be expected since politics and economy usually influence each other. As Alesina et al. ${ }^{63}$ argue, the pattern of trade openness and economic integration affects country formation and separation and vice versa.

Second, for the prominent role of social globalisation when variables are considered jointly, we provide some possible explanations. Polanyi ${ }^{64}$ observes that economic orders are not segregated from broader political and social orders and further argues the "embeddedness" of economic systems in broader social orders and that the understanding of market systems cannot be isolated from the realisation of the broader social orders in which they are located. Pepinsky ${ }^{6}$ indicates that the concept of embeddedness helps emphasise that the route towards financial development cannot deviate from the broader social and political structures in which economic action takes place. As life insurance is a sub-sector of the financial system, Pepinsky's argument should be applicable to life insurance markets. Our results reflect this perspective.

On the basis of Polanyi's ${ }^{64}$ and Pepinsky's ${ }^{6}$ arguments, this paper infers that sociocultural factors are latent elements for the development of the life insurance market. Economic factors, on the other hand, are explicit elements since higher income or improvement in economic conditions has a more direct effect on the purchase of life insurance. This can be reflected in Table 7 where globalisation in economic dimension has the largest effect on the convergence of life insurance markets in the world when the sub-dimension of globalisation is considered individually. However, when sociocultural factors are considered together, the effect of economic factors is tempered. This can be observed from some countries' life insurance development, for example, predominantly Muslim countries have high-income levels but smaller life insurance markets due to religious beliefs.

\section{Conclusion and remarks}

Applying the panel cointegration method to 39 countries over the period 1979-2007, this paper is the first to empirically investigate the impact of globalisation (including the overall index and various sub-indices) on the development and the convergence of

\footnotetext{
63 Alesina et al. (2000).

${ }^{64}$ Polanyi (1944).
} 
150

international life insurance markets. We follow $\mathrm{Enz}^{7}$ to estimate the deviation, in absolute terms, of international life insurance markets by subtracting the estimated world average from the life insurance penetration of an individual country. Evidence demonstrates that globalisation has a positive effect on the development of life insurance markets. Among sub-indices of globalisation, the economic and social dimensions are positively correlated with life insurance development and the effect of economic dimension is higher, but the political factor has no significant effect when considered individually. In addition, by examining the impact of globalisation on the deviation of life insurance penetration measured by the difference between observed life insurance penetration and the world average penetration, we find that globalisation could reduce the deviation of life insurance penetration as well, suggesting that globalisation promotes the convergence of international life insurance markets. In an interactive analysis, we find that social globalisation exerts a moderating effect on the influence of economic and political dimensions, but not vice-versa. Finally, the panel cointegration test with structural breaks shows that most countries' structural breaks coincide with the fast growth wave of international life insurance markets.

Our findings imply that socio-cultural factors are a latent factor for the development of local life insurance markets around the world. This suggests that local contingencies still dominate life insurance development in individual countries even if economic conditions have not been an impediment for life insurance consumption. The communication on socio-cultural aspects might be a driver for the similarity of life insurance development worldwide. Put more precisely, the favourable effect of economic or political globalisations on the development or the convergence of international life insurance markets could be enhanced through the assistance of socio-cultural globalisation. Governments need to concentrate more on the social dimension of globalisation by focusing on such aspects as international interactions, information technology or experiences of cultural communication.

\section{Acknowledgements}

The authors are grateful to the Editor and two anonymous referees for helpful comments and suggestions. Chien-Chiang Lee also thanks the National Science Council of Taiwan for financial support through grant NSC 100-2410-H-110-027-MY2. Please address correspondence to Chien-Chiang Lee.

\section{References}

Alesina, A., Spolaore, E. and Wacziarg, R. (2000) 'Economic integration and political disintegration', The American Economic Review 90(5): 1276-1296.

Arena, M. (2008) 'Does insurance market activity promote economic growth? A cross-country study for industrialized and developing countries', Journal of Risk and Insurance 75(4): 921-946.

Bai, J. and Perron, P. (2003) 'Computation and analysis of multiple structural change models', Journal of Applied Econometrics 18(1): 1-22.

Beck, T. and Demirgüç-Kunt, A. (2009) Financial institutions and markets across countries and over time: Data and analysis, World Bank Policy Research Paper No. 4943, Washington, D.C.

Beck, T. and Webb, I. (2003) 'Economic, demographic, and institutional determinants of life insurance consumption across countries', The World Bank Economic Review 17(1): 51-88. 
Berry-Stölzle, T.R., Hoyt, R.E. and Wende, S. (2010) 'Successful business strategies for insurers entering and growing in emerging markets', The Geneva Papers on Risk and Insurance-Issues and Practice 35(1): $110-129$.

Brown, D., Khagram, S., Moore, M.H. and Frumkin, P. (2000) 'Globalization, NGOs, and multisectoral relations', in J.S. Nye and J.D. Donahue (eds.) Governance in a Globalizing World, Washington, D.C.: Brookings Institution Press.

Carter, R.L. and Dickinson, G.M. (1992) Obstacles to the Liberalisation of Trade in Insurance, London: Harvester Wheatsheaf.

Caselli, M. (2008) 'Measuring ... what? Notes on some globalization indices', Globalizations 5(3): $383-404$.

Chang, C.-P. and Lee, C.-C. (2010) 'Globalization and economic growth: A political economy analysis for OECD countries', Global Economic Review 39(2): 151-173.

Chaudhary, S. (2008) 'The Indian Monsoon-Between a curse and a blessing', IRDA Journal 1(9): 33-36.

Chen, P.-F., Lee, C.-C. and Lee, C.-F. (2011) 'How does the development of the life insurance market affect economic growth? Some international evidence', Journal of International Development, DOI: 10.1002/jid.1785.

Choi, I. (2001) 'Unit root tests for panel data', Journal of International Money and Finance 20: 249-272.

Cummins, J.D. and Venard, B. (2008) 'Insurance market dynamics: Between global developments and local contingencies', Risk Management and Insurance Review 11(2): 295-326.

Di Vaio, G. and Enflo, K. (2010) 'Did globalization drive convergence? Identifying cross-country growth regimes in the long run', European Economic Review 55(6): 832-844.

Dreher, A. (2006a) 'Does globalization affect growth? Evidence from a new index of globalization', Applied Economics 38(10): 1091-1110.

Dreher, A. (2006b) 'IMF and economic growth: The effects of programs, loans, and compliance with conditionality', World Development 34(5): 769-788.

Dreher, A., Gaston, N. and Martens, P. (2008) Measuring Globalisation-Gauging Its Consequences, New York: Springer.

The Editorial Committee of China's Insurance Yearbook (2002) 2002 Yearbook of China's Insurance, Beijing, China: The Editorial Office of China's Insurance Yearbook.

The Editorial Committee of China's Insurance Yearbook (2010) 2010 Yearbook of China's Insurance, Beijing, China: The Editorial Office of China's Insurance Yearbook.

Engle, R.F. and Granger, C.W.J. (1987) 'Co-integration and error correction: Representation, estimation, and testing', Econometrica 55(2): 251-276.

Enz, R. (2000) 'The S-curve relation between per-capita income and insurance penetration', The Geneva Papers on Risk and Insurance - Issues and Practice 25(3): 396-406.

Fisher, R.A. (1932) Statistical Methods for Research Workers, $4^{\text {th }}$ edn. Edinburgh: Oliver \& Boyd.

Hussels, S., Ward, D. and Zurbruegg, R. (2005) 'Stimulating the demand for insurance', Risk Management and Insurance Review 8(2): 257-278.

Im, K.S., Pesaran, M.H. and Shin, Y. (2003) 'Testing for unit roots in heterogeneous panels', Journal of Econometrics 115(1): 53-74.

The Insurance Regulatory and Development Authority (2003) 'Report card: Life', IRDA Journal 1(6): 9-10.

Keohane, R.O. and Nye, J.S. (2000) 'Introduction', in J.S. Nye and J.D. Donahue (eds.) Governance in a Globalizing World, Washington D.C.: Brookings Institution Press, pp. 1-44.

Lee, C.C. and Chiu, Y.B. (2012) 'The impact of real income on insurance premiums: Evidence from panel data', International Review of Economics and Finance 21: 246-260.

Lepaud, J.P. (2008) 'Unit linked business_-Product development', IRDA Journal, 1(5): 12-14.

Levin, A., Lin, C.-F. and Chu, C.S. (2002) 'Unit root tests in panel data: Asymptotic and finite-sample properties', Journal of Econometrics 108(1): 1-24.

Lockwood, B. (2004) 'How robust is the Kearney/foreign policy globalisation index?' The World Economy 27(4): 507-523.

Lockwood, B. and Redoano, M. (2005) The CSGR globalisation index: An introductory guide, Centre for the Study of Globalisation and Regionalisation. Working Paper 155/04.

Ma, Y.-L. and Pope, N. (2008) 'Foreign share, insurance density, and penetration: An analysis of the international life insurance market', Risk and Management Review 11(2): 327-347.

Maddala, G.S. and Wu, S. (1999) 'A comparative study of unit root tests with panel data and a new simple test', Oxford Bulletin of Economics and Statistics 61: 631-652. 
152

Pedroni, P. (1999) 'Critical values for cointegration tests in heterogeneous panels with multiple regressors', Oxford Bulletin of Economics and Statistics 61: 653-670.

Pedroni, P. (2001) 'Fully modified OLS for heterogeneous cointegrated panels', Advances in Econometrics 15: 93-130.

Pedroni, P. (2001) 'Purchasing power parity tests in cointegrated panels', Review of Economics and Statistics 83(4): 727-731.

Pedroni, P. (2004) 'Panel cointegration: Asymptotic and finite sample properties of pooled time series tests with an application to the PPP hypothesis', Econometric Theory 20(3): 597-625.

Pepinsky, T.B. (2010) The political economy of financial development in Southeast Asia, Workshop for East Asian capitalism: Diversity, continuity and change, London School of Economics.

Polanyi, K. (1944) The Great Transformation: The Political and Economic Origins of Our Time, New York: Farrar \& Rinehart.

Randolph, J. (2001) G-index. Globalisation Measured, August World Markets Research Centre.

Sala-i-Martin, X. (1996) 'The classical approach to convergence analysis', The Economic Journal 106(437): $1019-1036$.

Sinha, T. (2007) 'An analysis of the evolution of insurance in India', in J.D. Cummins and B. Venard (eds.) Handbook of International Insurance: Between Global Dynamics and Local Contingencies, New York: Springer Science and Business Media, Inc., pp. 641-678.

Steger, M.B. (2004) Rethinking Globalism, Lanham, MD: Rowman \& Littlefield.

Sun, Q., Suo, L. and Zheng, W. (2007) 'China's insurance industry: Developments and prospects', in J.D. Cummins and B. Venard (eds.) Handbook of International Insurance: Between Global Dynamics and Local Contingencies, New York: Springer Science and Business Media, Inc., pp. 597-640.

Swiss Reinsurance Company (2008) 'World insurance in 2007: Emerging markets leading the way', No. 3.

Swiss Reinsurance Company (Various Years) Sigma, Zurich.

Wagner, M. and Hlouskova, J. (2010) 'The performance of panel cointegration methods: Results from a large scale simulation study', Econometric Reviews 29(2): 182-223.

Westerlund, J. (2006) 'Testing for panel cointegration with multiple structural breaks', Oxford Bulletin of Economics and Statistics 68: 101-132.

Zheng, W., Liu, Y. and Dickinson, G. (2008) 'The Chinese insurance market: Estimating its long-term growth and size', The Geneva Papers on Risk and Insurance - Issues and Practice 33(3): 489-506.

Zheng, W., Liu, Y. and Deng, Y. (2009) 'A comparative study of international insurance markets', The Geneva Papers on Risk and Insurance - Issues and Practice 34(1): 85-99.

\section{About the Authors}

Chien-Chiang Lee, Associate Professor of Department of Finance at National Sun Yat-Sen University. His research areas include banking and insurance. He is an Associate Editor of Energy Economics and has recent publications in Journal of Money, Credit and Banking, Macroeconomic Dynamics, International Review of Economics and Finance, The Geneva Risk and Insurance Review, The Geneva Papers on Risk and Insurance-Issues and Practice and Urban Studies.

Chi-Hung Chang, PhD candidate of Department of Finance at National Sun Yat-Sen University. His research interests are the development in financial and insurance markets and researches have been published or accepted in The Geneva Risk and Insurance Review, The Geneva Papers on Risk and Insurance-Issues and Practice and Journal of Business Economics and Management. 


\section{Appendix}

Table A1 Components of the 2009 KOF index of globalisation

A. Economic Globalisation

(i) Data on Actual Flows

Trade (per cent of GDP)

Foreign Direct Investment, flows (per cent of GDP)

Foreign Direct Investment, stocks (per cent of GDP)

Portfolio Investment (per cent of GDP)

Income Payments to Foreign Nationals (per cent of GDP)

(ii) Data on Restrictions

Hidden Import Barriers

Mean Tariff Rate

Taxes on International Trade (per cent of current revenue)

Capital Account Restrictions

B. Social Globalisation

(i) Data on Personal Contacts

Telephone Traffic

Transfers (per cent of GDP)

International Tourism

Foreign Population (per cent of total population)

International Letters (per capita)

(ii) Data on Information Flow

Internet Users (per 1000 people)

Televisions (per 1000 people)

Trade in Newspapers (percent of GDP)

(iii) Data on Cultural Proximity

Number of McDonald's Restaurants (per capita)

Number of Ikeas (per capita)

Trade in Books (per cent of GDP)

\section{Political Globalisation}

Embassies in Country

Membership in International Organisations

Participation in U.N. Security Council Missions

International Treaties

Source: Constructed by Dreher (2006a) and updated in Dreher et al. (2008). 
Table A2 Countries included in this study

\begin{tabular}{lll}
\hline Algeria & Greece & Norway \\
Argentina & India & Philippines \\
Australia & Indonesia & Portugal \\
Austria & Israel & Singapore \\
Belgium & Italy & South Africa \\
Brazil & Japan & Spain \\
Canada & Kenya & Sweden \\
Colombia & Korea & Switzerland \\
Denmark & Malaysia & Thailand \\
Egypt & Mexico & Tunisia \\
Finland & Morocco & United Kingdom \\
France & Netherlands & United States \\
Germany & New Zealand & Venezuela \\
\hline
\end{tabular}

